\title{
FACTOR STRUCTURE AND MAJOR FACTORS OF PHYSICAL ABILITY OF 13-14-YEAR-OLD PUPILS
}

\section{Mariana Borukova}

National Sports Academy „Vassil Levski”, Sofia, Bulgaria

\begin{abstract}
Physical activity is an important element and criterium for a healthy lifestyle. The level of physical ability determines the degree to which an organism adapts to its environment and therefore the development and condition of all the other personal qualities depends greatly on it. One of the elements of physical ability and fitness is the main motor qualities - speed, strength, endurance, agility, flexibility, balance, coordination of movements.

The aim of that study is to reveal the major factors of physical ability of 13-14-year-old pupils, as well as to determine to what extent gender differences influence the level of physical ability between boys and girls of one age group. We used variation, factor and comparative analyses when we processed the results. According to the general conclusions, for both boys and girls there are three major factors with a very high percentage to the initial dispersion of the surveyed phenomenon. We can sum up that in this age group the established gender differences have a very big impact on the physical ability of the pupils, and these differences regard mostly the explosive power of the lower limbs, the speed abilities and the endurance of the kids, the advantage being totally in favor of the boys.
\end{abstract}

Key words: pupils, adolescents, factor structure and physical ability

\section{INTRODUCTION}

Nowadays the issue about saving and supporting adolescents' physical health is quite topical. Modern technology has been an intrinsic part of young people's daily round since an early age. Both youngsters' insufficient physical load and their improper and bad diet lead to their reduced physical ability.

The aim of the education system is to provide conditions for the proper development and support of children's physical and psychic health, as well as their harmonious development as able and active persons.

Physical activity is an important element and criterium for a healthy lifestyle. The level of physical ability determines the degree to which an organism adapts to its environment and therefore the development and condition of all the other personal qualities depends greatly on it. We would not go far by stating that physi- cal fitness is a prerequisite, a condition for the development of a harmoniously developed personality. It provides enough resources for a better health, great efficiency in educational, professional and home activities, for better quality of life (Dimitrova, 1997, Popivanova, 2007). One of the elements of physical ability and fitness is the main motor qualities - speed, strength, endurance, agility, flexibility, balance, coordination of movements. The tests for evaluation of these qualities and the markers for physical development turn into major indexes of a person's health status. The way of life of the contemporary generation is characterized with reduced motor activity, lower physical ability and a generally worse healthy status, which has been pointed out in a number of scientific manuscripts (Petkova, Kvartirnikova 1985, Slanchev et al,1992, Popivanova, 2007). The research was done among secondary school pupils. At 
this stage of their education they should acquire a general sports knowledge and general physical preparation. In compliance with the state educational requirements (SER) pupils receive a mark for the level of their physical fitness. Kids nowadays find it very difficult to cope with the physical tests applied so far. In this relation, a national research was carried out on a large scale over a six-month period to establish the physical fitness of pupils (1st to 12th grade) in order to design a new test battery for their evaluation. Such kind of testing had not been conducted in Bulgaria for the last 25 years. The pupils we tested are part of this research.

The complex development of physical qualities poses the issue of evaluation and control of the level of physical preparation of pupils. Such studies are conducted on school and university level as well. The authors (Mavrudieva, 2008; Mavrudieva et al, 2017) consider speed, strength and agility to be the leading factors of physical ability at a more mature age. The revealing of the factor structure of physical ability has a high information value for the optimization of pupils' education process (Tzarova, Borukova, 2012).

Similar surveys were carried out in Macedonia and Romania (Saiti, 2013; Bădicu,2017). With the help of the compulsory tests (four for preliminary and four for secondary schools) provided by the national system for evaluation of physical education and sport, the dynamics and mobility of the 7-14-year-old pupils was observed. It will be interesting to point out that only one of these tests made in Macedonia and Romania, coincides with those, applied in Bulgaria, namely long jump. The best results were recorded exactly along this test.

The analysis of the abovementioned facts, our personal experience and observations enable us to formulate the following work hypothesis: we assume that the present study will enable us to determine and identify the major factors which influence to the greatest extent physical ability of 13-14-year-old pupils.

The aim of the present study is to reveal the major factors of physical ability of 13-14-year-old pupils, as well as to determine to what extent gender differences influence the level of physical ability between boys and girls of one age group.

\section{METHODOLOGY}

The study was carried out in October - December 2018.

The research was aimed at studying the main indexes of physical fitness of 13-14-yearold pupils (boys and girls) and was done among 61 pupils at a humanitarian secondary school in the town of Shumen.

For the purposes of the research we tested the pupils along 5 indexes which carry information about the main indexes of physical fitness. These are:

$\checkmark$ Running $30 \mathrm{~m}$;

$\checkmark$ Long jump with both feet from place;

$\checkmark 3 \mathrm{~kg}$ medicine ball throwing with both hands from standing position;

$\checkmark$ Running 200 m.;

$\checkmark$ Agility and space coordination test (Hunting test)

The four tests: Running $30 \mathrm{~m}$, Standing Long jump with both feet, $3 \mathrm{~kg}$ medicine ball throwing with both hands from standing position and Running $200 \mathrm{~m}$ are standard tests applied in physical education and sport classes. The only new test is the Test for agility and spatial coordination. Description: Four small rubber hoops (with a diameter $15-20 \mathrm{~cm}$ ) are placed in the shape of the letter T (Figure 1). There is one tennis ball in each hoop. Actions: the pupil stands in front of the hoop at the start/finish spot in initial position: upright, feet shoulder-width apart. At the starting signal the pupil bends down, takes the ball from inside the hoop and moves to the rest of the hoops in the 


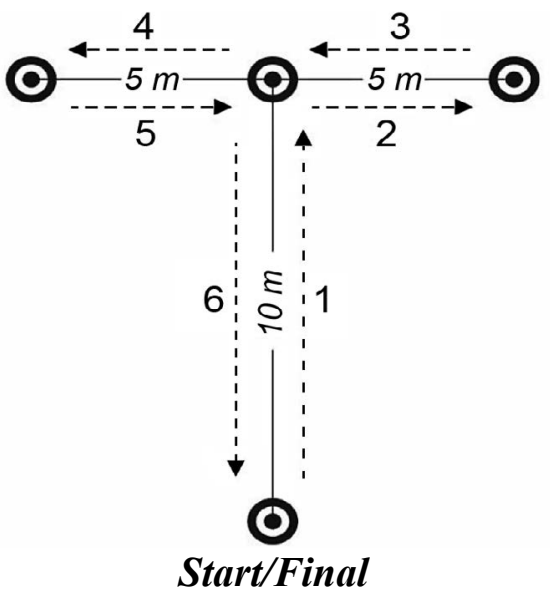

Figure 1. Hunting test

direction indicated with figures from 1 to 6 (see Figure 1).

Pupils take the ball from every hoop leaving the one they have taken from the previous hoop. The recording ends as soon as the ball touches the area of the hoop at the start/finish point and is measured with accuracy of up to $0.01 \mathrm{sec}$.

\section{Research methods and indexes}

In order to fulfil the set tasks and aim of the research we applied the following methods: $a$ detailed study of the specialized literature and sports-pedagogical testing.

\section{Procedure}

The sports-pedagogical tests were applied by the same researcher within three sessions with 21 pupils during their regular classes. The testing was carried out by the school and the teachers of the researched individuals. Pupils' anonymity was guaranteed because all of them were recorded under different numbers. The respondents took part in the research voluntarily and did not receive any monetary or financial compensation for their contribution. None of the participants refused to take part. They were provided with brief instructions, video and demonstration. In standard settings - a gym and a running track in the school yard, with the necessary equipment: a stopwatch, measurement equipment and medicine ball $-3 \mathrm{~kg}$, each participant executed each test twice. In the analysis of the results the better scores were used.

\section{Data analysis}

The results from the research were processed with math-statistical methods such as: variation, factor and comparative analyses with t-criterion of Student for independent samples (Gigova, 2002). All analyzes were developed using the Social Science Statistical Package (SPSS, version 19.0)

Three major factors were established which characterize the specific peculiarities of the researched individuals.

\section{RESULTS}

The results from the variation analysis of the observed indexes of physical fitness (Table 1) show that the values have a normal distribution, and the researched individuals are relatively homogeneous as regards the characteristics these indexes provide information for.

Table 1. Mean values and variability of the indexes of physical fitness

\begin{tabular}{|c|c|c|c|c|c|c|c|c|c|}
\hline № & Indexes & $\mathbf{N}$ & Min & Max & $\mathbf{X}$ & $\mathbf{S}$ & $\mathbf{V}$ & As & $\mathbf{E x}$ \\
\hline 1. & Running $30 \mathrm{~m}$ & 61 & 4,13 & 6,76 & 5,45 & 0,63 & 11,64 & $-0,094$ & $-0,909$ \\
\hline 2. & Standing Long jump & 61 & 110,00 & 250,00 & 165,35 & 31,97 & 19,34 & 0,693 & $-0,141$ \\
\hline 3. & $3 \mathrm{~kg}$ medicine ball throwing & 61 & 195,00 & 830,00 & 466,40 & 130,15 & 27,91 & 0,503 & $-0,076$ \\
\hline 4. & Running $200 \mathrm{~m}$ & 61 & 25,67 & 63,90 & 45,91 & 7,18 & 15,63 & $-0,032$ & 0,149 \\
\hline 5. & Agility test & 61 & 11,92 & 26,36 & 15,74 & 2,25 & 14,27 & 1,694 & 6,974 \\
\hline
\end{tabular}


For the purposes of the research we divided the researched individuals along gender (female and male pupils) and applied factor analysis.

The factor structure of 13-14-yesr-old male pupils consists of 3 major factors (Table 2) which explain a very high percentage of the initial dispersion of the surveyed phenomenon $(91,28 \%)$.

Table 2. Factor structure of physical ability of 13-14-yesr-old male pupils

\begin{tabular}{llccccc}
\hline № & Indexes & I & II & III & $\mathbf{h}^{\mathbf{2}}$ & $\mathbf{1 - h}^{\mathbf{2}}$ \\
\hline 1. & Running 30 m &, 658 &, 649 &,- 054 &, 858 &, 142 \\
2. & Standing Long jump &,- 653 &,- 451 &, 447 &, 830 &, 170 \\
3. & 3 kg medicine ball throwing &,- 196 &,- 107 &, 963 &, 977 &, 023 \\
4. & Running 200 m &, 876 &, 316 &,- 250 &, 930 &, 070 \\
5. & Agility test &, 331 &, 910 &,- 163 &, 964 &, 036 \\
\hline \multicolumn{2}{|c}{$\sum \mathrm{a}^{2}=91,28 \%$} & $68,39 \%$ & $16,41 \%$ & $6,37 \%$ & &
\end{tabular}

Besides the factor weights, the table presents the data about the size of the explained $\left(\mathrm{h}^{2}\right)$ and the unexplained $\left(1-\mathrm{h}^{2}\right)$ initial dispersion of each surveyed index.

The analysis of Table 2 shows that the first established factor explains $68,39 \%$ of the initial dispersion of the surveyed phenomenon. The following two factors have a smaller contribution to the pupils' general physical fitness, $16,41 \%$ and $6,37 \%$ respectively.

The first factor in the factor structure of the physical fitness of 13-14-year-old male pupils is determined by three indexes and as we have already stated, it explains the highest percentage of the initial dispersion of the surveyed phenomenon $(68,39 \%)$. This factor is related to the explosive power of the lower limbs in horizontal efforts, speed abilities and the endurance of the boys.

The second factor is determined by only one factor which is related to the special orientation and agility of the pupils.

The third factor in the factor structure of the physical fitness of 13-14-year-old pupils explains the smallest percentage $(10,95 \%)$ of the initial dispersion of the surveyed phenomenon. This index is related to the strength of the male pupils' shoulder girdle.

The factor structure of 13-14-yesr-old female pupils also consists of 3 major factors (Table 3) which explain the high percentage of the initial dispersion of the surveyed phenomenon $(89,18 \%)$.

Table 3. Factor structure of physical ability of 13-14-yesr-old female pupils

\begin{tabular}{|c|c|c|c|c|c|c|}
\hline № & Indexes & $\mathbf{I}$ & II & III & $\mathbf{h}^{2}$ & 1-h ${ }^{2}$ \\
\hline 1. & Running $30 \mathrm{~m}$ & 847 &,- 206 & ,295 & ,847 &, 153 \\
\hline 2. & Standing Long jump &,- 675 &, 552 &,- 197 & ,799 & ,201 \\
\hline 3. & $3 \mathrm{~kg}$ medicine ball throwing &,- 094 & ,962 &,- 103 & ,944 & ,056 \\
\hline 4. & Running $200 \mathrm{~m}$ & ,908 &,- 010 &, 212 &, 870 &, 130 \\
\hline 5. & Agility test & ,316 &,- 139 & ,938 & ,999 &, 001 \\
\hline
\end{tabular}

The analysis of table 3 shows that the first established factor explains $59,69 \%$ of the initial dispersion of the surveyed phenomenon, while the following two factors have a much smaller percentage - $18,31 \%$ and $11,18 \%$.

The first factor in the factor structure of the physical fitness of 13-14-year-old female pupils is also determined by three indexes, like those of the boys, but here the initial dispersion of the surveyed phenomenon is explained with less than $10 \%$ of them. This factor is related to the explosive power of the lower limbs in horizontal efforts, speed abilities and the girls' ability to run $200 \mathrm{~m}$. 
The second factor is determined by only one factor $(18,31 \%)$, which is related to the explosive power of the female pupils' shoulder gridle, while the same factor is related to the boys' agility.

The third factor in the factor structure of the physical fitness of 13-14-year-old female pupils explains the smallest percentage $(11,18 \%)$ of the initial dispersion of the surveyed phenomenon. This is the index related to the girls' agility and their spatial orientation.

The analysis of the results presented in tables 2 and 3 shows that as regards the explained dispersion of the surveyed phenomenon there are some differences in the percentage correlation and the weight of the factors when we compare the boys and the girls. The indexes included in the first factor are the same for both groups, but with the boys the percentage of the explained dispersion is $68,39 \%$, while with the girls it is $59,69 \%$. The second factor with the boys is related to agility and spatial orientation, while the second factor with the girls is related to the explosive power of upper limbs.

The development of the quality strength shows a pronounced dependence between gender and age. The research of Kirsten
(1963) shows that with the 11-14-year-old the strength training has the same effect for boys and girls. Later, when they are 15-16 years old, there is an increase in girls' strength compared with boys', nevertheless the same training method is applied. It has been established that the gender differences are more greatly expressed in the strength of the muscles of the limbs and significantly less in the strength of the core muscles (Borukova, 2018). With pubescence, which is observed at the age of 11-13 nowadays, the increase of the strength drops, but after the age of 14-15 it increases sharply reaching its maximum values between the age of 18 and 20.

From methodological point of view, the coordination of the movements is viewed as a component of agility. The sensitive periods for the development of the coordination abilities are those between 7 and 12 years and after puberty, but the highest indexes appear at the age of 13-14.

It is important for us to find out whether there are some differences between the mean values of the boys and girls besides the factor weights of the surveyed indexes.

The comparative analysis of the mean values of the two groups is presented in Table 4.

Table 4. Comparative analysis of the mean values of the surveyed indexes of the two groups

\begin{tabular}{ccccc}
\hline Indexes & Boys/girls & $\mathbf{N}$ & $\mathbf{X}$ & $\mathbf{S}$ \\
\hline \multirow{2}{*}{ Running $30 \mathrm{~m}$} & boys & 27 & 5,11 & 0,642 \\
& girls & 34 & 5,71 & 0,504 \\
\hline \multirow{2}{*}{ Long jump } & boys & 27 & 182,37 & 33,685 \\
& girls & 34 & 152,65 & 23,873 \\
\hline \multirow{2}{*}{3 kg medicine ball throwing } & boys & 27 & 537,04 & 139,361 \\
& girls & 34 & 412,85 & 93,530 \\
\hline \multirow{2}{*}{ Running $200 \mathrm{~m}$} & boys & 27 & 41,29 & 5,422 \\
& girls & 34 & 49,48 & 6,412 \\
\hline \multirow{2}{*}{ Agility test } & boys & 27 & 15,10 & 2,0518 \\
& girls & 34 & 16,24 & 2,327 \\
\hline
\end{tabular}

We can see in the table that in running 30 $\mathrm{m}$ boys are $0.60 \mathrm{sec}$ faster than girls, in $200 \mathrm{~m}$ - they are about $8 \mathrm{sec}$ faster. There are bigger differences in the long jump where the boys have higher values of $0,30 \mathrm{~cm}$ at average; they throw $120 \mathrm{~cm}$ farther the medicine ball, and in the agility test they are $1 \mathrm{sec}$ faster.

The comparative analysis of the mean val- 
ues does not provide us with sufficient information. The analysis of the table of variances shows that along one of the indexes (agility test) there are some deviations from the normal distribution as regards both asymmetry (As) and excess (Ex). As a whole, however, we can assume that the set of indexes used has a normal distribution.
In order to prove the differences between the average levels of the two groups, we applied a comparative analysis with t-criterion of Student for independent samples at a high guarantee probability $\mathrm{Pt} \geq 99 \%$ and a coefficient value higher than $t_{\text {critical }}=3,46$.

The significance of the differences between the two groups is presented in Figure 2.

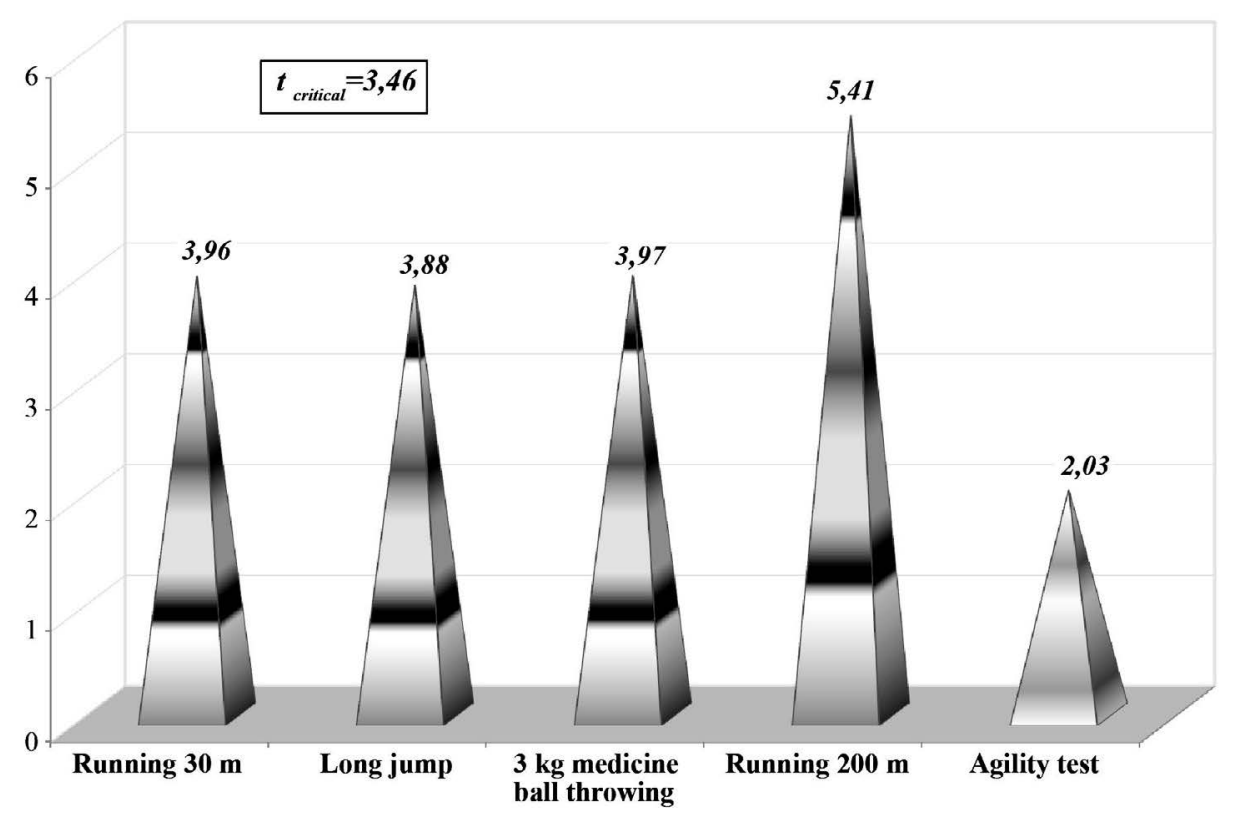

Figure 2. Significance of the differences of the mean values between boys and girls (13-14 -years-old)

After the application of the criterion we found out that there were statistically significant differences between the average levels of the indexes of physical fitness of the two groups along four of the surveyed indexes. These are the indexes related to speed abilities, explosive power of lower and upper limbs, and the pupils' endurance. With $99 \%$ guarantee probability we can claim that the 13-14-year-old boys are better as regards these indexes. As regards agility and special orientation, there is no statistically significant difference between the boys and the girls. The existing differences between the two groups can be explained with fortuitous reasons.

\section{CONCLUSIONS}

The analysis of the results and the general look at the factor structure of the physical fitness of 13-14-year-old pupils allows us to draw the following conclusions:

1. The coefficient of variation of the students at a secondary school shows that the researched individuals are relatively homogeneous as regards the observed indexes of physical fitness.

2. For the 13-14-year-old pupils (boys and girls) the most important is the factor revealing the high significance of:

$\checkmark$ speed abilities;

$\checkmark$ explosive power of the lower limbs, and $\checkmark$ the endurance to run $200 \mathrm{~m}$.

3. The following factor have a smaller contribution to the physical fitness of the 13-14-year-old pupils:

$\checkmark$ the explosive power of the upper limbs, and $\checkmark$ agility and special orientation. 
4. The comparative analysis enables us to claim that, along four of the indexes, the boys are superior to their female peers. The differences are statistically significant along four indexes. As regards agility, there is no statistically significant difference between the boys and the girls.

The analysis of the integral factor structures of the physical fitness of 13-14-year-old pupils who took part in the research shows there are three factors established for both groups which explain a high percentage of the initial dispersion - 91,28\% for the boys and $81,18 \%$ for the girls, respectively.

We could sum up that the established gender differences in this age group have a great influence on the physical fitness of the pupils, and these differences are more strongly manifested in the explosive power of the lower and upper limbs than in the children's speed abilities and endurance - the advantage being in total favor of the boys.

It would have been better for the purposes of the research if we had been provided with the information about the pupils' height and weight, so we could have calculated their BMI. This would have helped the analysis of the results. The sports-pedagogical testing, however, aims at designing a new Normative System for evaluation of the physical fitness of the secondary school pupils in Bulgaria and that is why only five tests were included.

During this age period children's physical and psychic qualities are developed the most intensively. The physical development and perfection of a child's organism, the gain in health and the increase of vitality, hardening, obtaining motor and hygienic habits, which are specific tasks of the physical education and sport among adolescents, are closely related to the other sides of education: mental, labor, aesthetic, moral.

\section{REFERENCES}

Aleksieva, M. (2010). Varianti za optimizirane izjvite na podrastvashti igrachi po basketbol, Pedagogicheski almanah, UI „Sv. Sv. Kiril I Metodij“. // Алексиева, М. (2010). Варианти за оптимизиране изявите на подрастващи играчи по баскетбол, (студия). Педагогически алманах, УИ „Св. св. Кирил и Методий”.

Bădicu, G. (2017). The dynamics of mobility in the light of the assessment of mandatory tests, introduced in the national system of evaluation, in students in primary and second educational stages. Journal Plus Education. ISSN 1842-077X, E-ISSN (online) 20681151, vol. XVIII, pp. 112-121.

Borukova, M. (2018). Upravlenie i control na sportnata podgotovka pri 13-14 godishni basketbolistki. Sofia, Bolid ins. // Борукова, M., (2018). Управление и контрол на спортната подготовка при 13-14 годишни баскетболистки. София, Болид-инс

Borukova, M., (2014). Factor structure and basic factors of the physical development and the specific workability of growing up basketball players (12-19 years old). Proceeding Book of 4th FIEP Congress and 7th International Congress "Sport, Stress, Adaptation". Physical Education and Sport, Competence for life, 9-12 October 2014. pp. 287-296.

Bujar, S. (2013). Tables For Evaluation Of The Motor Capabilities Of 10 Years Old Male Pupils In Rebublic Of Macedonia, FIEP BULLETIN. Volume 83 - Special Edition - ARTICLE III, pp. 340-342

Dimitrova, S. (1993). Intelekt I sport. VFK, Sofia. // Димитрова, Св. (1993). Интелект и спорт., ВФК, София, 1993 г.

Gigova, V. (2002). Statisticheska obrabotka I amaliz na Danni, Sofia, NSAIPB. // Гигова, В., (2002). Статистическа обработка и анализ на данни, София, НСА - ИПБ. 
Giocheva, K., Tzarova R., Tzarov. Kr. (1990). Sisrema za kojrol, otzenka I optimtzirane na sportnata podgotovka na momicheta I momcheta - 13-15 godini. Sofia, ETZNPKFKS-IPB, pp.6. // Гьошева, К., Р. Цьрова, К. Църов, (1990). Система за контрол, оценка и оптимизиране на спортната подготовка на момичета и момчета - 13-15 години. София, ЕЦНПКФКС - ИПБ, стр.6.

Kirsten G. (1963). Der Einfluss isometrischen Muskeltrainings auf die Entwicklung der Muskelkraft Jugendlicher Internationale Zeitschrift für Angewandte Physiologie Einschliesslich. Argbeitsphysiologie; vol. 19, pp. 387-402

Mavrudieva, N. (2008). Factorna struktura na fizicheskata godnost I sportno-tehnicheskite umenia na uchenitzi ot VI klas na SOU. Sport \& nauka, Izvanreden broi 4, pp. 172183). // Маврудиева, Н. (2008). Факторна структура на физическата годност и спортно-техническите умения на ученици от VI клас на СОУ. Спорт и наука. Извънр. Брой 4, с. 173-183.

Mavrudieva, N., Zhunisbek, D., Mavrudiev, P., Kuleva, M. (2017). Factorial structure of physical development and physical ability of students. Proceeding book of the International Congress "Applied Sports Sciences", Sofia, pp. 417-420.

Petkova, L., Kvartirnikova, M. (1985). Tes- tove za ozenjavane na fizicheskata deesposobnost. Sofia, Medicina \& Fizkultura. // Петкова, Л., Квартирникова, М. (1985). Тестове за оценяване физическата дееспособност. София, Медицина и Физкултура.

Popivanova, Tzv. (2007). Namalenata dvigatelna aktivnost na uchenizite I riska ot osteoporoza. Sport \& nauka, br. 1, Sofia, pp. 32. // Попиванова, Цв., (2007). Намалената двигателна активност на учениците и риска от остеопороза. Спорт и наука, брой 1, София, стр.32.

Slanchev, P. (1992). Sportna medicina: Uchebnik za student ot NSA. Sofia, Medicina I fizkultura. // Слънчев, П. (1992). Спортна медицина: Учебник за студенти от НCA, София, Медицина и физкултура.

Tzarova, R. (2013). Problemi na kontrola $v$ basketbola, Sofia, Bolid ins. // Църова, Р. (2013). Проблеми на контрола в баскетбола. София. Болид инс.

Tzarova, R., Borukova, M. (2011). Izsledvane varhu nivoto na na podgotvenost na uchenieziteq kandidatstvashti v sportni uchilishta $\mathrm{s}$ profil basketbol. Sport \& nauka, izv. broi 2, pp. 89-97. // Църова, Р., Борукова, М. (2011). Изследване върху нивото на подготвеност на учениците, кандидатстващи в спортните училища с профил баскетбол. Спорт \& наука, (Изв. брой 2.) стр. 89-97.

\section{Corresponding author:}

Mariana Borukova

Department „Basketball, Volleyball, Handball”

National Sports Academy „Vassil Levski” Studentski grad, 21, Acad. Stefan Mladenov Str.

Sofia 1700, Bulgaria E-mail: marianaborukova@gmail.com 